\title{
PENERIMAAN PESAN SEKS PRANIKAH OLEH PENONTON DALAM FILM DUA GARIS BIRU
}

\author{
Shania Nurul Syarifa', Catur Nugroho² \\ ${ }^{1}$ Telkom University, Bandung, Indonesia, email : shanianrlsyfr@gmail.com \\ 2Telkom University, Bandung, Indonesia, email : mas_pires@yahoo.com
}

\begin{abstract}
This research aims to knowing audience's reception about the meaning of the message about impact of premarital sex contained in the Dua Garis Biru film. This research uses a qualitative method with descriptive research through the theory of reception (reception analysis) from Stuart Hall. The purpose of this research was to look at the position of the audience's based on data that was obtained through the interview with three audience's position readings according to the Stuart Hall concern the impact of premarital sex in the Dua Garis Biru film. The three positions are dominant reading, negotiated reading, and oppositional reading. Based of the research result show that the audience's in the dominant reading position, they can receive all the message delivered by the Dua Garis Biru film about premarital sex but with a different perspectives. They still reject the premarital sex, even though they are in a "relationship". The informants interpreted the impact of premarital sex and claimed to have received many messages about the dangers of premarital sexual behavior. They also revealed that after watching the film their thoughts were influenced by the existence of premarital sex which is mostly happening in this era.
\end{abstract}

Keywords: Reception Analysis, meaning, Premarital of Sex, Film.

\begin{abstract}
ABSTRAK
Penelitian ini bertujuan untuk mengetahui penerimaan audiens tentang makna pesan mengenai dampak seks pranikah yang terkandung dalam film Dua Garis Biru. Penelitian ini menggunakan metode kualitatif dengan penelitian deskriptif melalui teori resepsi (reception analysis) dari Stuart Hall. Tujuan dari penelitian ini adalah untuk melihat posisi audiens berdasarkan data yang diperoleh melalui wawancara dengan bacaan posisi tiga audiens menurut Stuart Hall menyangkut dampak seks pranikah dalam film Dua Garis Biru. Tiga posisi tersebut adalah pembacaan dominan, negosiasi, dan oposisi. Berdasarkan hasil penelitian menunjukkan bahwa penonton dalam posisi membaca dominan, mereka dapat menerima semua pesan yang disampaikan oleh film Dua Garis Biru tentang seks pranikah tetapi dengan perspektif yang berbeda. Mereka masih menolak hubungan seks pranikah, meskipun mereka berada dalam sebuah "hubungan". Para informan menafsirkan dampak hubungan seks pranikah dan mengklaim telah menerima banyak pesan tentang bahaya perilaku seksual pranikah. Mereka juga mengungkapkan bahwa setelah menonton film, pikiran mereka dipengaruhi oleh keberadaan seks pranikah yang sebagian besar terjadi di era ini.
\end{abstract}

Kata Kunci : Analisis Resepsi, pemaknaan, Seks pra Nikah, Film.

Received: 04-03-2020

Revision: 20-03-2020
Acceptance: 15-04-2020

Published online: $30-05-2020$ 


\section{PENDAHULUAN}

Seiring berkembangnya zaman, maka perkembangan pergaulan anak muda juga mulai berubah bahkan mayoritas sudah mulai mengikuti budaya kebarat-baratan yang kadang tidak sesuai dengan budaya yang ada di Indonesia. Jika dilihat kembali, banyak ditemui antara remaja laki-laki dan perempuan yang menjalin pertemanan lebih dari sekedar teman biasa, atau biasa kita sebut dengan istilah pacaran. Hal tersebut tentunya sudah menjadi gaya hidup zaman sekarang, terlebih perilaku pacaran banyak dilakukan oleh anak-anak, remaja, hingga dewasa. Pacaran tentunya dilakukan oleh remaja zaman sekarang demi melampiaskan rasa suka yang mereka alami kepada lawan jenisnya. Kebanyakan remaja sekarang merasa jika orang yang tidak pernah pacaran akan dianggap kuper, norak dan ketinggalan zaman. Pacaran bagi remaja zaman sekarang malah lebih menjerumus ke hal-hal yang negatif. Kebanyakan remaja yang berpacaran sudah berani bersentuhan dengan lawan jenisnya, seperti berpegangan tangan, berpelukan, hingga melakukan hal yang lebih intim seperti berciuman. Hal tersebut nantinya akan menimbulkan kelakukan menyimpang yang menjerumus kepada perilaku seksual. Perilaku seksual remaja, khususnya seks pranikah masih mendominasi hingga zaman sekarang. Perilaku tersebut menimbulkan banyak dampak negatif yang akan dirasakan pada pelaku sendiri dan juga lingkungannya.

Menurut Sarwono dalam (Khairunnisa, 2013), mengatakan bahwa perilaku seksual adanya tingkah laku yang didorong oleh hasrat seksual seseorang yang dilakukan baik dengan lawan jenis maupun sesama jenis dengan cara melakukan kontak fisik. Objek dari hasrat seksual tersebut bisa melalui khayalan, diri sendiri maupun kepada orang lain. Bentuk dari tingkah laku tersebut bermacam-macam, dimulai dari munculnya perasaan saling tertarik antar lawan jenis ataupun sesama jenis, lalu mulai melakukan kegiatan berkencan, hingga bersetubuh dan bersenggama.

Di Indonesia sendiri perilaku seksual remaja setiap tahun semakin meningkat. Dilansir berdasarkan data melalui website resmi BKKBN (Administrator SDKI 2018), (Badan Kependudukan dan Keluarga Berencana Nasional) pada tahun 2018 sebanyak 56\% remaja di Indonesia sudah pernah melakukan seks pra-nikah. Kebanyakan remaja yang melakukan kegiatan seks pra-nikah berawal dari rasa ingin tahu melihat sebuah konten yang berbau 
pornografi dan juga dorongan dari pasangannya tanpa memikirkan dampak buruk yang timbul seperti kehamilan, mencoreng nama baik keluarga, dan penyakit menular seksual.

Kehamilan pranikah juga banyak menyebabkan resiko yang dapat membahayakan orang tua dan juga bayi yang dikandung. Hubungan seks yang dilakukan diluar ikatan pernikahan dapat menyebabkan penyakit menular seksual seperti HIV (Human Immunodeficiency Virus) dengan pasangan yang berbeda-beda. Kehamilan pranikah di Indonesia banyak dialami oleh remaja yang berusia 15-20 tahun dimana dengan rentang usia tersebut sangat memiliki resiko besar, seperti resiko keguguran yang lebih besar, gangguan hipertensi dalam kehamilan, kelahiran premature diikuti dengan kondisi dengan berat badan lahir rendah (BBLR), serta terjadinya baby blues pada ibu.

Berdasarkan hal diatas, maka edukasi mengenai seks pranikah sangat penting diajarkan sejak usia dini untuk mengurangi resiko-resiko kehamilan di usia muda ataupun angka kehamilan diluar ikatan pernikahan. Banyak hal yang dapat terjadi jika melakukan perilaku seksual pranikah yang menyebabkan kerugian kepada diri sendiri dan juga orang di sekitar. Edukasi seksual tentunya tidak hanya bisa didapatkan melalui pendidikan di sekolah, melalui internet, tetapi bisa melalui film dengan melihat makna secara visual. Kebanyakan masyarakat sekarang mendapatkan edukasi seksual hanya melalui artikel-artikel yang ada di internet tanpa melihat secara nyata makna edukasi seksual yang digambarkan secara visual bila dilihat melalui film. Zaman sekarang perfilman sudah mulai memunculkan film dengan makna edukasi yang bermacam-macam salah satunya yakni edukasi seksual. Film sudah dikemas sedemikian rupa agar penonton dapat memahami makna positif yang terkandung didalamnya tanpa melihat sisi negatif makna film tersebut.

Film "Dua Garis Biru" disutradarai oleh Ginatri S. Noer yang di produksi oleh PT. Kharisma Starvision Plus pada tahun 2019. Film tersebut menceritakan kisah dua remaja yang masih duduk di bangku SMA namun harus bertanggungjawab pada sebuah kesalahan besar akibat ulah mereka sendiri. Semua cita-cita yang telah disusun setelah lulus SMA harus dikubur dalam-dalam akibat permasalah tersebut. Terdapat konflik yang terjadi dalam dua keluarga baik dari pihak laki-laki maupun perempuan. Bagaimana mungkin seorang anak SMA sudah bisa melakukan hal yang diluar batas jika bukan karena tanpa adanya pengawasan dari orang tua. 
Dijelaskan pula dalam film tersebut dampak yang timbul akibat hamil diluar nikah dan resiko mengandung yang dialami oleh perempuan yang berusia masih 17 tahun. Diperlihatkan juga bagaimana kecewanya kedua orang tua ketika tahu bahwa anaknya telah melakukan kesalahan fatal dan harus mempertanggungjawabkan semuanya pada usia yang belum waktunya, terlebih bagi orang tua yang memiliki anak perempuan.

Film “Dua Garis Biru” menjelaskan secara rinci mengenai edukasi tentang bahaya dari melakukan seks pra-nikah terlebih jika dilakukan oleh remaja di usia dini. Pengemasan film tersebut dikemas secara menarik terlebih dalam setiap adegan dan juga mimik wajah karakter menampilkan pesan sehingga penonton dapat mengerti arti pesan yang terkandung tanpa harus disampaikan melalui teks naskah. Dalam adegan film juga menampilkan dari sisi kekeluargaan, dimana pentingnya sebuah komunikasi yang terjadi antara anak dengan orang tua serta proses memaafkan satu sama lain terhadap sebuah kesalahan besar dalam perjalanannya untuk menjadi lebih baik. Tidak hanya menjelaskan unsur pendidikan mengenai seks yang komprehensif saja, tapi mengandung unsur lainnya. Film ini dianggap mampu menjelaskan kepada masyarakat melalui komunikasi verbal ataupun non-verbal mengenai dampak dari perilaku seks pranikah, sehingga pesan-pesan yang disampaikan dalam film tersebut mampu diterima secara utuh dan melalui pemikiran yang positif oleh masyarakat tanpa harus menampilkan adegan-adegan vulgar yang dapat mengubah persepsi dari pemikiran masyarakat. Hal tersebut menjadi dasar alasan mengapa film "Dua Garis Biru" ini dipilih sebagai bahan dasar dari penelitian ini.

Film “Dua Garis Biru” berhasil mendapatkan prestasi dan respon positif dari masyarakat sejak awal penayangannya di tanggal 11 Juli 2019 di bioskop. Dilansir melalui akun Instagram (duagarisbirufilm 2019), pada saat tujuh hari penayangan, film tersebut mampu menarik sebanyak 1.235.354 penonton dari berbagai kota di Indonesia. Selain itu film "Dua Garis Biru" juga masuk kedalam lima nominasi Festival Film Bandung 2019. Hal tersebut tentunya membuat film "Dua Garis Biru" menempati posisi kedua film Indonesia terlaris tahun 2019 setelah posisi pertama ditempati oleh film "Dilan 1991" yang mampu meraih sebanyak 5.253.411 penonton. 
Selain itu, film "Dua Garis Biru" berhasil mendapatkan beberapa penghargaan diantaranya lewat "Festival Film Bandung", menjadi pemenang sebagai film bioskop terpuji, film bioskop dengan penulis skenario terpuji, dan film bioskop dengan penata artistik terpuji. Selanjutnya dalam "JAFF-ISA (Jogja Asian Festival Fim-Indonesian Screen Awards) sebagai Best Film JAFF-ISA 2019, Best Director JAFF-ISA 2019, dan Best Script JAFF-ISA 2019. Dalam Festival Film Indonesia 2019 Gina S. Noer terpilih sebagai "Penulis Skenario Asli Terbaik" dan Cut Mini sebagai “Pemeran Pendukung Wanita Terbaik FFI 2019". Film Dua Garis Biru juga masuk ke dalam lima nominasi “FESTIVAL FILM TEMPO” diantaranya sebagai “Film Pilihan Tempo (Dua Garis Biru)", "Sutradara Pilihan Tempo (Gina S. Noer)", “Aktor Pilihan Tempo (Angga Yunanda)”, "Aktris Pendukung Pilihan Tempo (Cut Mini Theo)", dan "Skenario Pilihan Tempo (Gina S. Noer)". Penghargaan terakhir yang diperoleh oleh Film Dua Garis Biru ialah terpilih sebagai Film Pilihan Asumsi 2019 oleh media dan website Asumsi. Hingga hari akhir penayangan film ini mampu meraih sebanyak 2.538.363 penonton dari seluruh kota di Indonesia.

Dibalik terjadinya kontroversi, film "Dua Garis Biru" akhirnya mampu menarik banyak penonton mulai dari remaja hingga dewasa mampu memahami segala makna yang terkandung didalam setiap adegan tentang bahayanya perilaku seks pra-nikah yang dilakukan oleh remaja. Khalayak sebagaimana disampaikan Turner, dapat menggunakan media untuk merefleksikan ketertarikan pada preferensi atau hal yang lebih disukai (West \& Turner, 2008). Namun, menurut Baran, khalayak dapat menolak pengaruh-pengaruh yang disebabkan oleh media jika terjadi ketimpangan dan pertentangan dengan pemahaman lain sehingga menganggap orang lain pasif dalam menciptakan sebuah makna demi mengikuti keinginan media (Baran \& Davis, 2015). Sementara Stuart Hall menyampaikan bahwa penonton bertindak secara aktif dalam memanfaatkan dan mengkonsumsi pesan media, dalam sebuah proses sirkular encoding dan decoding (Durham, Meenakshi Gigi and Kellner, 2006).

Untuk mengukur pemaknaan suatu khalayak media menggunakan sudut pandang teori analisis resepsi. Penonton bukanlah khalayak pasif, tetapi merupakan khalayak aktif sebagai penghasil sebuah makna, maka penonton sangat memiliki pengaruh besar dalam penghasil sebuah makna tersebut. Menurut Barker, teori resepsi memiliki pengertian bahwa khalayak dipengaruhi oleh faktor kontekstual dalam membaca sebuah media seperti film atau acara 
televisi. Makna muncul berdasarkan hasil interprestasi seseorang yang dipengaruhi oleh latar belakangnya, selain itu pemaknaan teks tidak dapat dipisahkan dari pengalaman maupun pengetahuan suatu khalayak terhadap teks-teks lainnya (Barker, 2003).

Analisis resepsi menekankan bahwa adanya penerimaan makna sebuah teks yang diterima oleh khalayak melalui imajinasi para pembacanya. Pemaknaan teks media tersebut harus dibaca melalui persepsi khalayaknya. Bagaimana media tersebut menampilkan teks sehingga audience dapat memahami bentuk komunikasi yang disampaikan melalui teks dalam media. Khalayak biasanya akan lebih mudah menangkap sebuah pesan berdasarkan apa yang dilihatnya bukan apa yang didengarnya. Pada teori pemaknaan (reception) yang dikemukakan oleh Stuart Hall dalam (Durham, Meenakshi Gigi and Kellner, 2006) memiliki artian tentang bagaimana khalayak memiliki hubungan saat berinteraksi dengan teks yang ada pada media dan memaknai teks tersebut. Khalayak yang aktif dalam memaknai sebuah teks dapat diketahui melalui model encoding dan decoding yang dikemukakan oleh Stuart Hall dengan maksud memahami pesan meskipun pesan tersebut bersifat transparan dan dilakukan dengan satu arah akan tetapi memungkinkan untuk diterima dan dipahami dengan cara yang berbeda.

Model encoding dan decoding yang dikatakan oleh Stuart Hall meliputi bahwa: (a) encoding disebut sebagai proses dan alat untuk membuat sebuah pesan (dalam konteks sosial dan politik), (b) decoding dapat diartikan sebagai memperoleh makna dari pesan dengan mendasar sehingga mudah dipahami. Reproduksi pesan dapat dicegah jika audience tidak dapat menerjemahkan pesan tersebut. Pada intinya, analisis resepsi membuat audience dapat memahami isi dari teks media dengan cara mengartikan melalui preferensi masing-masing dan berfokus pada tahap decoding (Durham, Meenakshi Gigi and Kellner, 2006) .

Dari film “Dua Garis Biru” pemaknaan audiens terhadap perilaku seks pra-nikah dapat dilihat melalui bagaimana audience tersebut bisa memahami pesan-pesan yang disampaikan melalui setiap adegan yang terkandung didalam film tersebut. Maka dari itu melalui penelitian ini peneliti akan mengangkat mengenai pemaknaan audiens khususnya remaja akhir dengan rentang usia 18-23 tahun yang berstatus "pacaran" yang memiliki latar belakang dan budaya yang berbeda-beda tentang seks pra-nikah yang terkandung dalam film "Dua Garis Biru”. 
Melalui film Dua Garis Biru pemaknaan audiens dapat dilihat dengan dampak perilaku seks pranikah yang ditampilkan melalui setiap adegan. Berdasarkan informasi dan uraian diatas, maka permasalahan yang muncul adalah bagaimana audiens memaknai adegan dampak seks pranikah yang ada dalam film Dua Garis Biru. Melalui adegan-adegan yang menampilkan dampak seks pranikah, audiens diharapkan dapat menerima makna pesan yang disampaikan khususnya pada remaja yang sedang menjalin hubungan "pacaran".

Film merupakan sebuah karya dengan menggunakan unsur sinematografi dalam berbagai bentuk, jenis dan ukuran melalui berbagai rangkaian proses dengan suara ataupun tanpa suara untuk ditayangkan, dipertunjukkan dengan bantuan alat elektronik atau sistem proyeksi mekanik sebagai media komunikasi massa. Menurut Dennis McQuail, film sebagai teknologi baru mulai muncul sejak akhir abad ke-19 namun masih jarang memunculkan konten. Kemudian seiring berkembangnya teknologi, film mulai memunculkan unsur cerita dalam bentuk panggung musik, drama, hiburan dan juga humor guna dikonsumsi khalayak (McQuail, 2014). Film juga mampu menjangkau khalayak dengan jumlah yang sangat besar hingga ke wilayah yang sulit dijangkau, maka dari itu film dikatakan sebagai media massa yang sesungguhnya.

Dalam konteks komunikasi massa, menurut Jay Black dan Frederick C. Whitney dalam (Kartika, 2015) film merupakan produk yang memiliki fungsi-fungsi yang menjadi kekhasan dari perilaku komunikasi massa, sebagaimana yang dikemukakan oleh antara lain: (1) to inform (menginformasikan), (2) to entertain (memberi hiburan), (3) to persuade (membujuk), (4) transmission of the culture (transmisi budaya). Dalam sudut pandang yang berbeda, sebuah film dan teater memiliki komunikasi yang berbeda serta memiliki pengaruh langsung terhadap terjemahan teks film dibandingan teks drama.

Delabastita menyebutkan, untuk menjangkau khalayak film memiliki sarana visual dalam menyampaikan sebuah pesan agar tidak bingung dalam memahami kode-kode yang digunakan untuk menghasilkan sebuah makna film yang sebenarnya (Delabastita, 1989). Produser dan konsumen biasanya membuat beberapa sistem untuk memungkinkan khalayak memahami kode pada film yang bermakna. Menurut McQuail, penonton sering dipahami dengan istilah audience, secara sederhana dapat diartikan sekumpulan manusia yang melakukan kegiatan 
menonton atau menyaksikan, dan mendengarkan tayangan dalam media (McQuail, 2014). Secara konseptual seseorang yang memahami suatu fenomena dengan mengkonsumsi media dalam berbagai cara dan kebutuhan dengan melihat, dan mendengarkan tayangan yang disajikan dalam media, lalu menciptakan makna sesuai dengan apa yang ditangkap. Secara garis besar, arti khalayak media menurut Sterling (dalam (Nasrullah, 2018)) didefinisikan mengenai karakteristik dari khalayak itu sendiri yang bersifat indivual dan terkontrol, dengan artian bahwa antara khalayak tidak saling mengenal satu sama lain sehingga feedback yang diberikan oleh khalayak menjadi terstruktur.

\section{METODE}

Pada penelitian ini dilakukan dengan menggunakan metode kualitatif deskriptif melalui pendekatan analisis resepsi yang berusaha memaparkan kejadian atau fenomena yang diteliti untuk kemudian dibandingkan hasil data-data yang ada dan berhubungan dengan resepsi penonton film Dua Garis Biru yang dijadikan sebagai bahan penelitian. Analisis resepsi menciptakan makna atau pesan yang disampaikan oleh sebuah media kepada audiens yang memandang audiens sebagai producer of meaning yang aktif dalam menciptakan makna, bukan hanya sebagai konsumen dari isi media. Audiens berusaha menginterpretasikan pesan dalam media sekaligus mengkonstruksi pesan tersebut melalui pengalam sosial-budaya masing-masing individu melalui analisis resepsi.

Pengumpulan data dalam penelitian ini diambil dari beberapa sumber informasi dengan menggunakan teknik pengumpulan data yang bermacam-macam (triangulasi) yang dilakukan secara terus menerus. Dalam penelitian ini teknik pengumpulan data dilakukan melalui beberapa cara, yaitu dengan wawancara mendalam (In-depth Interview), yaitu melakukan wawancara dengan pertanyaan yang bersifat terbuka guna menggali informasi dari responden

dengan menggunakan daftar pertanyaan yang telah dipersiapkan oleh peneliti. Selanjutnya peneliti juga melakukan observasi terkait dengan topik penelitian, yaitu melakukan pengamatan dengan cara menonton langsung film Dua Garis Biru. 


\section{HASIL DAN PEMBAHASAN}

Film Dua Garis Biru merupakan sebuah karya film Indonesia yang disutradarai oleh Ginatri S. Noer dan diproduksi oleh Starvision Plus dan dirilis pada tangga 11 Juli 2019. Film ini menggaet dua aktor remaja yakni Angga Yunanda dan Adhisty Zara (Zara Jkt48) dan beberapa aktor senior lainnya seperti Lulu Tobing, Dwi Sasono, Cut Mini, Arswendi Nasution, dan Rachel Amanda dengan durasi film yakni berjumlah 113 menit. Film bercerita tentang sepasang remaja yaitu Bima (Angga Yunanda) dan Dara (Zara Jkt48) yang harus berhadapan dengan kehidupan yang tidak pernah terbayangkan oleh anak seusia mereka, yaitu menjadi orangtua akibat kesalahan fatal yang mereka lakukan. Bima berasal dari keluarga biasa yang tinggal di daerah perkampungan dan tingkat keagamaan yang tinggi. Ibunya adalah seorang penjual gado-gado yang sudah terkenal didaerah rumahnya, dan ayahnya seorang ketua RT. Dara sendiri berasal dari keluarga yang berada dan tinggal ditengah kota. Ibunya merupakan seorang wanita karir sedangkan ayahnya merupakan pemilik salah satu cafe yang ada di Jakarta.

Berawal pada saat Bima berkunjung kerumah Dara sehabis pulang sekolah, lalu mereka bermain didalam kamar Dara. Pada awalnya Bima dan Dara hanya saling bercanda, namun tanpa diduga mereka berdua sampai melakukan hal-hal yang seharusnya belum boleh dilakukan sesuai mereka. Tanpa Bima dan Dara sadari dampaknya tidak hanya akan kepada mereka sendiri, tetapi juga kepada keluarga dan lingkungan mereka. Dara merasa kaget dengan apa yang telah dia lakukan dengan Bima, namun Bima masih bersikap biasa saja. Sampai akhirnya pada saat sedang makan kerang bersama teman-temannya, Dara merasakan ada yang aneh dengan dirinya. Dara tiba-tiba merasa mual hingga akhirnya muntah. Bima dan temantemannya tidak ada yang curiga dengan keanehan pada diri Dara termasuk ibunya. Ibu Dara tidak curiga sama sekali, dan masih menganggap bahwa Bima merupakan anak baik-baik.

Hingga suatu hari, dimana Dara sedang mengobrol dengan adiknya Puput, Dara mulai menyadari bahwa ia sudah mengalami telat menstruasi. Dara langsung memberitahukan hal tersebut kepada Bima. Keesokannya Bima mendatangi rumah Dara dan membelikan alat tes kehamilan (testpack). Pada awalnya Dara merasa ragu-ragu untuk mencoba testpack tersebut. Hingga akhirnya hasil testpack menunjukkan dua garis biru, yang berarti Dara positif hamil. Pada saat Dara dikamar mandi, Bima melihat-lihat seisi kamar Dara dan menunjukkan bahwa Dara sangat menyukai korea dan bercita-cita ingin melanjutkan sekolah kesana. 
Bima terlihat menghindari Dara di sekolah karena merasa bingung dan merasa bersalah sehingga tidak tahu harus berbuat apa. Sementara Dara terus mengejar Bima untuk meminta pertanggungjawaban. Ibu Bima yang melihat sikap aneh dari anaknya langsung merasa curiga dan langsung menyimpulkan bahwa Bima sudah terjerat dengan narkoba. Ayah Bima yang bijaksana berusaha untuk menanyakan keadaan Bima secara baik-baik sehingga Bima tidak merasa dihakimi. Bima hanya bisa menangis saat menceritakan masalahnya, tetapi ia belum jujur kepada kedua orangtuanya dan hanya mengatakan bahwa ia telah melakukan sebuah kesalahan besar. Dara ingin mengambil keputusan besar untuk menggugurkan kandungannya, namun pada saat Bima dan Dara sudah tiba ditempat "aborsi", Dara langsung mengurungkan niatnya karena merasa tidak tega untuk membunuh bayi yang tidak bersalah. Sempat terjadi keributan antara Bima dan Dara hingga akhirnya mereka mengambil keputusan untuk melanjutkan kehamilan Dara dan berencana memberitahukan kepada orangtua mereka pada waktu yang tepat.

Dara sempat mengalami kecelakaan pada saat mata pelajaran olahraga, dimana hal tersebut membuat Bima dan Dara dalam masalah besar. Tanpa sengaja Dara memberitahukan bahwa dirinya hamil sehingga kedua orangtua mereka dipanggil ke sekolah. Dara harus kehilangan statusnya sebagai siswi disekolah. Kedua orangtua Dara dan Bima merasa sangat terpukul sehingga Bima harus melakukan tanggungjawab kepada Dara atas masalah mereka. Kehamilan yang dialami Dara tidaklah mudah, mengingat usianya masih dibawah umur. Dara berpeluang mengalami keguguran jika terlalu capek atau bayinya terlahir tidak sempurna.

Dara harus dihadapkan dengan realita kehidupan keluarga yang sebenarnya, hingga akhirnya kedua orangtua Bima dan Dara memutuskan untuk menikahkan mereka demi bayi yang dikandung Dara. Setelah menikah Dara dan Bima harus dihadapkan dengan masalahmasalah yang belum pernah mereka hadapi sebelumnya. Bima harus bekerja sepulang sekolah untuk bisa membiayai Dara sedangkan Dara harus belajar untuk tetap bisa mengikuti ujian paket C. Bima dan Dara tidak bisa menikmati masa-masa bermain mereka seperti anak SMA pada umumnya.

Kedua orangtua Dara yang menganggap bahwa anaknya harus menggapai cita-citanya, memutuskan untuk memberikan cucunya kepada orang lain untuk diurus dan Bima harus 
bercerai dari Dara. Keluarga dari pihak Bima tidak menyetujui hal tersebut dan menganggap bahwa keluarga Dara sudah mempermainkan pernikahan. Dara tetap pada niatnya ingin melanjutkan sekolah ke Korea yang sudah ia impikan sejak kecil. Selalu terjadi konflik baik antara Dara dengan kedua orangtuanya, orangtua Bima dengan orangtua Dara, hingga antara Bima dan Dara. Sampai akhirnya Dara melahirkan, namun mereka harus dihadapkan dengan kenyataan bahwa Dara harus melakukan operasi pengangkatan rahim karena mengalami pendarahan hebat. Hal ini terjadi karena usia Dara yang tidak memungkinkan untuk mengalami kondisi melahirkan. Di akhir film, Dara harus tetap pergi ke Korea sedangkan bayi mereka akan diurus oleh Bima dan keluarganya.

Dari hasil wawancara mengenai gambaran umum tentang film Dua Garis Biru, kelima informan mengaku mengetahui film tersebut melalui media sosial dan juga rekomendasi dari orang terdekat. Hal yang membuat informan tertarik untuk menonton film Dua Garis Biru adalah mereka menganggap film tersebut mengangkat isu yang masih dianggap sensitif oleh masyarakat Indonesia yakni mengenai seks pranikah dan ingin melihat motif dibalik perilaku tersebut. Beberapa informan juga menyebutkan hal yang mereka dapatkan setelah menonton film Dua Garis Biru adalah bagaimana pentingnya sex education untuk masyarakat Indonesia, dampak yang berbahaya bagi pelaku ataupun lingkungannya, dan juga konflik-konflik keluarga, serta cara menghadapi masalah akibat perilaku seks pranikah tersebut.

Setelah mengetahui isu yang diangkat dalam film Dua Garis Biru mengenai seks pranikah, kelima informan menjelaskan definisi perilaku seks pranikah menurut pendapat mereka masing-masing. Kelima informan berpendapat bahwa perilaku seks pranikah merupakan hubungan intim yang dilakukan selayaknya sepasang suami istri diluar adanya ikatan pernikahan yang sah baik secara hukum maupun agama. Untuk mengetahui latar belakang informan mengenai perilaku seks pranikah, peneliti memberikan pertanyaan mengenai apakah informan pernah menjadi pelaku atau korban dari perilaku seks pranikah itu sendiri. Dari kelima informan, tiga informan menjawab tidak pernah melakukan perilaku seks pranikah, namun dua informan mengaku pernah melakukan seks pranikah dengan kasus yang berbeda. 
Berdasarkan hasil wawancara dari kelima informan, beberapa berpikir bahwa hal tersebut akan membawa dampak yang sangat buruk akibat kurangnya edukasi. Dan beberapa informan lainnya berpikir untuk lebih berhati-hati dan meningkatkan pengetahuan yang cukup untuk mengurangi dampak dan efek negatif dari seks pranikah tersebut. Dari kelima informan juga mengaku tidak menerima adanya perilaku seks pranikah yang dilakukan oleh remaja berpacaran dimana hal tersebut seharusnya dilakukan oleh pasangan yang sudah sah menikah, namun kembali lagi kepada pribadi setiap masing-masing individu, dan juga kesadaran dari individu tersebut.

Selanjutnya peneliti menanyakan apakah menurut informan ada adegan dalam film Dua Garis Biru yang berpengaruh dalam menampilkan dampak seks pranikah. Informan 1 menjawab bahwa ia melihat adegan yang paling berpengaruh dalam menampilkan dampak seks pranikah di film Dua Garis Biru ketika pertama kali Dara ketahuan hamil dan konflik yang terjadi antara orangtua Dara dan Bima akibat kecewa. Pertanyaan selanjutnya adalah peneliti menanyakan apakah peran orangtua sangat berpengaruh terhadap perilaku seks pranikah. Kelima informan menjawab bahwa peran orangtua sangat berpengaruh untuk mengatur pola pikir anak agar tidak terjerumus ke perilaku seks pranikah. Informan 4 berpendapat bahwa film Dua Garis Biru lebih menekankan kepada orangtua dikarenakan film tersebut banyak menampilkan bagaimana orangtua harus berperan dalam menyikapi sebuah masalah besar yang terjadi kepada anaknya.

Terlihat dari hasil wawancara bahwa kelima informan sangat setuju dengan peran orangtua yang sangat berpengaruh terhadap perilaku seks pranikah. Mereka beranggapan bahwa pola pikir seorang anak dapat dilihat melalui bagaimana cara orangtua mendidik anak tersebut. Informan 4 memiliki pendapat bahwa film Dua Garis Biru lebih menekankan target kepada orangtua dalam berperan mendidik anak. Untuk mengenai cara menyikapi perilaku seks pranikah pada era sekarang, beberapa informan mengaku untuk lebih bisa menjaga diri sendiri terlebih kepada perempuan, dan beberapa informan lainnya mengaku menyikapi hal tersebut dengan biasa saja karena itu sudah menjadi urusan pribadi seseorang dan menjadi tanggung jawab pribadi masing-masing.

Berdasarkan hasil wawancara terlihat bahwa pesan verbal yang diterima informan berasal dari dialog dimana ibunya Dara mengatakan bahwa pekerjaan menjadi orangtua 
terutama menjadi seorang ibu merupakan pekerjaan seumur hidup. Seorang ibu berperan penting untuk anaknya dimulai ketika anak tersebut kecil hingga menikah dan memiliki seorang anak. Salah seorang informan juga menyebutkan bahwa pesan verbal yang ia terima bahwa seorang anak yang berasal dari keluarga religius juga bisa terjerumus kedalam pergaulan hingga melakukan seks bebas.

Setiap informan menerima pengaruh pemikiran yang berbeda-beda dari pesan yang disampaikan film Dua Garis Biru mengenai dampak seks pranikah. Beberapa informan mengatakan bahwa ia lebih mengetahui dampak dan bahaya dari seks pranikah sendiri terlebih pentingnya pendidikan seks bagi masyarakat Indonesia yang masih menganggap hal tersebut sangat sensitif untuk diperbincangkan. Beberapa lainnya merasa takut dan berusaha untuk meminimalisir agar hal tersebut tidak terjadi dikarenakan efek buruknya sangat berpengaruh untuk fisik dan juga psikologis pelaku. Selain itu dampak yang sangat besar juga akan terjadi terhadap lingkungan sosial disekitar kita.

Makna pesan yang paling banyak disampaikan dalam film Dua Garis Biru adalah pentingnya komunikasi yang terjalin didalam keluarga terutama antara ibu dan anak. Seperti jawaban ketiga informan, seorang anak harus bisa meluangkan waktunya untuk berkomunikasi dan menceritakan hal-hal yang terjadi dalam hidupnya. Lain halnya dengan informan lainnya, makna pesan yang diterima berupa pentingnya memiliki pengetahuan lebih mengenai seks dan juga peran orangtua yang sangat penting dalam mengatur pola pikir anak.

Para informan menegaskan bahwa seks pranikah hanya akan membawa dampak buruk terhadap pelaku dan juga masa depan pelaku. Selain itu, keterlibatan keluarga juga akan berpengaruh. Informan lainnya juga menganggap bahwa seks pranikah sangat tidak boleh dilakukan, dimana hal tersebut hanya merupakan kenikmatan sesaat yang memiliki risiko sangat tinggi jika dilakukan dengan rasa penasaran. Dampak lainnya juga akan menimbulkan penyakit terutama pada perempuan sehingga akan membuat hancurnya psikis dan kepercayaan diri pada perempuan.

Hasil analisis diatas menunjukkan bahwa pada dampak seks pranikah berdasarkan adegan yang paling berpengaruh, kelima informan berada pada tipe Negotiated Code (Negosiasi). Hal tersebut dikarenakan keempat informan memiliki pandangan yang berbeda 
dengan adegan paling berpengaruh dalam menampilkan dampak seks pranikah. Pada informan 1 hingga informan 4, mereka memiliki pandangan yang sama terhadap satu adegan yang sangat berpengaruh menampilkan dampak seks pranikah. Seperti yang diungkapkan oleh informan 1 yang mengatakan bahwa :

"Mungkin yang paling berkesan di dalam UKS, ya sepanjang shoot itu menceritakan emotional feel yang tinggi dan dapet banget, dari sisi anak, sisi orangtua, dan sisi lingkungan sosialnya juga dapat banget".

Sedangkan informan 5 memiliki pandangan tersendiri yang berbeda dengan keempat informan lainnya. la mengaku memiliki adegan tersendiri yang sangat berpengaruh dalam menampilkan dampak seks pranikah. Seperti yang dikatakan oleh informan 5 yang berpendapat:

"Terus si cowoknya jadi lebih protektif apalagi pas scene yang olahraga. Dia juga sempat di usir kan sama orangtuanya, udah sih, paling lebih kasihan ke ceweknya."

Untuk selanjutnya yaitu pesan verbal yang disampaikan terhadap dampak seks pranikah. Sama halnya seperti dampak seks pranikah berdasarkan adegan yang paling berpengaruh, dalam hal ini posisi informan berada pada tipe Dominant Reading. Sama seperti sebelumnya, keempat informan memiliki pandangan yang sama terhadap pesan verbal yang mereka lihat, sedangkan informan lainnya memiliki pandangan yang berbeda namun semua informan memiliki pemahaman yang sama terhadap pesan verbal tersebut. Seperti yang dikatakan oleh informan 1 dan mewakili pandangan ketiga informan lainnya mengatakan bahwa,

"Seingat aku ya, pesan verbal yang pertama itu pas Ibunya bilang ke anaknya kalau jadi ibu itu nggak hanya 9 bulan aja, tapi seumur hidup. Dimana maksudnya jadi ibu itu nggak gampang."

Dan informan 3 yang memiliki pendapat berbeda dari keempat informan lainnya berpendapat bahwa,

"Sebenarnya dari dialog ada saya masih inget, kalau nggak salah dari orangtuanya si Bima terutama ibunya. Ya intinya kenapa sih kamu bisa melakukan itu, sementara keluarga mereka sendiri dari keluarga yang agamis." 
Pertanyaan selanjutnya adalah bagaimana pesan dalam film Dua Garis Biru dapat mempengaruhi pemikiran informan terhadap dampak seks pranikah. Dari kelima informan semuanya memiliki pemikiran yang berbeda-beda setiap individu. Seperti informan 1 mengatakan bahwa film Dua Garis Biru dapat menjadi pelajaran bagi anak-anak sekarang terhadap dampak seks pranikah yang ditampilkan.

"Di film ini tuh menyampaikan banget semua pesan dari bahaya sampai dampak seks pranikah, bisa jadi pelajaran juga sih buat anak-anak sekarang yang lagi pacaran."

Sementara informan 2 mengatakan pentingnya sex education bagi masyarakat Indonesia khususnya remaja.

"Pengaruhnya itu penonton jadi paham banget bahwasanya sex education itu penting dan di Indonesia sendiri masih terlalu sensitif."

Informan 3 mengatakan hampir keseluruhan dari film Dua Garis Biru dapat mempengaruhi pemikirannya mengenai dampak seks pranikah dikarenakan efek buruk terhadap fisik dan psikologis yang ditayangkan.

"Ya secara keseluruhan dari 3/4 filmnya deh. Itu beneran ketakutan dari efek buruk fisik dan psikologis."

Sedangkan informan 4 menjawab bahwa ia ingin lebih meminimalisir kejadian dari seks pranikah dengan cara melakukan timeline waktu bertemu dengan pasangan.

"Ya kalau pacaran sebaiknya diadakan timeline untuk ketemu, gimana caranya kita meminimalisir kejadian itu. Tetap jalan berdua, tapi sama keluarga."

Informan 5 mengatakan bahwa ia merasa takut setelah melihat dampak seks pranikah dalam film Dua Garis Biru karena efek sampingnya yang sangat besar terhadap lingkungan sosial.

"Pas gua nonton filmnya sih takut ya, jujur takut. Ga nyangka bakal se-chaos itu. Tapi lebih ngadepin ke lingkungan sih sama tanggung jawab."

Setelah memastikan informan menonton film Dua Garis Biru secara penuh, peneliti menanyakan makna pesan mengenai seks pranikah yang diterima oleh informan. Sama seperti sebelumnya, kelima informan memiliki opini yang berbeda-beda sesuai pemikiran mereka setelah menonton film Dua Garis Biru. 
Informan 1 menjawab bahwa ternyata dampak seks pranikah bisa berpengaruh terhadap masa depan pelaku dan merusak nama baik keluarga.

"Ternyata seks pranikah itu bakalan ngehancurin masa depan si pelaku dan intinya dampaknya besar banget sih. Bisa ke diri sendiri, apalagi kalau sampai hamil pasti akan melibatkan keluarga."

Sama halnya seperti informan 1, informan 2 juga memiliki jawaban yang sama mengenai makna pesan seks pranikah dalam film Dua Garis Biru. la merasa seharusnya seks pranikah tidak dilakukan sebelum menikah karena akan merusak cita-cita yang sudah diimpikan, khususnya pada remaja.

"Karena kan kalau seks pranikah pas remaja, kita punya cita-cita masing-masing gitu. Salah satunya berdampak pada masa depan. Terus hubungan seks itu memang seharusnya nggak dilakuin sebelum nikah."

Sementara informan 3 berpendapat bahwa seks pranikah hanya akan memiliki risiko yang tinggi jika dilakukan dengan rasa penasaran.

"Ini kalau dilakukan dengan rasa penasaran, memiliki risiko yang tinggi sekali. Ya hanya kenikmatan sesaat yang nggak worth it sama sekali."

Sedangkan informan 4 mengatakan bahwa kepercayaan diri dan psikis seseorang akan hancur jika melakukan seks pranikah.

"Seks pranikah itu ngebuat hancurnya psikis dan kepercayaan diri seseorang, karena janin yang belum kuat jadi hancur sehingga nggak bisa punya anak lagi."

Informan 5 sama seperti informan 2 mengatakan bahwa seks pranikah seharusnya tidak boleh dilakukan, namun ia lebih menyerahkan hal tersebut kepada individu masing-masing."

"Ya, itu nggak boleh. Cuman balik lagi, itu terserah mereka aja."

Dengan latar belakang informan yang sedang menjalani hubungan dengan status "berpacaran", peneliti juga menanyakan apakah informan pernah menjadi pelaku atau korban dari perilaku seks pranikah. Ketiga informan mengaku tidak pernah melakukan seks pranikah karena menurut mereka seks pranikah hanya akan membawa dampak buruk dan berbuat dosa.

Seperti jawaban informan 1, yaitu 
"Alhamdulillah sih enggak. Karena dari akunya sendiri sih masih mikirin buat masa depan ya, terus lebih takut ke dosa sih sama dampaknya aja."

Lain halnya dengan informan 3 dan informan 4, mereka mengakui bahwa pernah melakukan seks pranikah namun tidak sampai terjadi kehamilan. Seperti yang dikatakan oleh informan 4 : "Kalau untuk sampai hal yang kayak gitu dan punya anak sih enggak, tapi kalau pernah melakukan, pernah.

Tabel 1. Pembacaan Audiens Terhadap Dampak Seks Pranikah

\begin{tabular}{|c|c|c|c|c|}
\hline Resepsi & \multirow[t]{2}{*}{$\begin{array}{c}\text { Dominant } \\
\text { Reading }\end{array}$} & \multirow[t]{2}{*}{$\begin{array}{c}\text { Negotiated } \\
\text { Reading }\end{array}$} & \multirow[t]{2}{*}{$\begin{array}{c}\text { Oppositional } \\
\text { Reading }\end{array}$} & \multirow[t]{2}{*}{ Keterangan } \\
\hline Dampak Seks Pranikah & & & & \\
\hline $\begin{array}{l}\text { Adegan : } \\
\text { - } \quad \text { Ruangan UKS } \\
\text { - } \quad \text { Jembatan } \\
\text { - } \quad \text { Saat Olahraga }\end{array}$ & $\begin{array}{c}\text { Informan } \\
\begin{array}{c}1,2,3,4 \\
\text { dan } 5\end{array}\end{array}$ & & & $\begin{array}{l}\text { Informan memiliki pendapat yang } \\
\text { berbeda-beda terhadap adegan yang } \\
\text { ditampilkan mengenai dampak seks } \\
\text { pranikah. Dari kelima informan, } \\
\text { empat informan memiliki pandangan } \\
\text { yang sama terhadap satu adegan } \\
\text { yang menampilkan dampak seks } \\
\text { pranikah. }\end{array}$ \\
\hline $\begin{array}{l}\text { Pesan Verbal : } \\
\text { - "Kamu pikir gampang jadi } \\
\text { orangtua?" } \\
\text { - "Dar, jadi orangtua itu bukan } \\
\text { hanya hamil } 9 \text { bulan } 10 \text { hari. Ini } \\
\text { tanggung jawab seumur hidup" } \\
\text { - "Itu kontraksi, bu. Ini ciri-ciri } \\
\text { kehamilan yang beresiko } \\
\text { keguguran. Dara ini butuh } \\
\text { bedrest" } \\
\text { "Jadi kehamilan di usia Dara ini } \\
\text { resikonya sangat tinggi" } \\
\text { "Ketika di usia ini hamil, maka } \\
\text { badannya merasakan } 2 \text { kali } \\
\text { lipat dari orang-orang yang } \\
\text { kehamilannya di usia yang } \\
\text { sudah siap" } \\
\text { "Tubuhnya Dara itu belum }\end{array}$ & $\begin{array}{l}\text { Informan } \\
\begin{array}{c}1,2,3,4 \\
\text { dan } 5\end{array}\end{array}$ & & & $\begin{array}{l}\text { Informan beranggapan berdasarkan } \\
\text { dialog-dialog tersebut sangat } \\
\text { menampilkan pesan verbal mengenai } \\
\text { dampak seks pranikah yang ditujukan } \\
\text { kepada khalayak. Keempat informan } \\
\text { memiliki pemikiran yang sama } \\
\text { terhadap satu dialog yang } \\
\text { menjelaskan bahwa menjadi } \\
\text { orangtua bukanlah pekerjaan yang } \\
\text { mudah. Menurut keempat informan } \\
\text { dialog tersebut sangat } \\
\text { menyampaikan pesan mengenai } \\
\text { dampak seks pranikah. }\end{array}$ \\
\hline
\end{tabular}


siap, yang artinya butuh dukungan moral yang lebih besar lagi"

- "Kamu harus jagaian biar dia nggak stress, dan juga penuhi gizi ibu dan bayinya"

- "Kamu juga harus belajar tentang ciri-ciri kelainan pada kehamilan"

- "Tentang resiko melahirkan, misalnya kalau terjadi pendarahan saat melahirkan"

- "Harusnya kita sering ngobrol kayak gini ya, Bim"

- “Coba aja dari dulu ibu kasih tahu kamu, pasti tidak akan kejadian"

- "Ini yang ibu tidak mau, kalau Adam harus diambil orang lain"

- "Kamu itu orangtuanya, dan kamu harus sering ngobrol dengan dia"

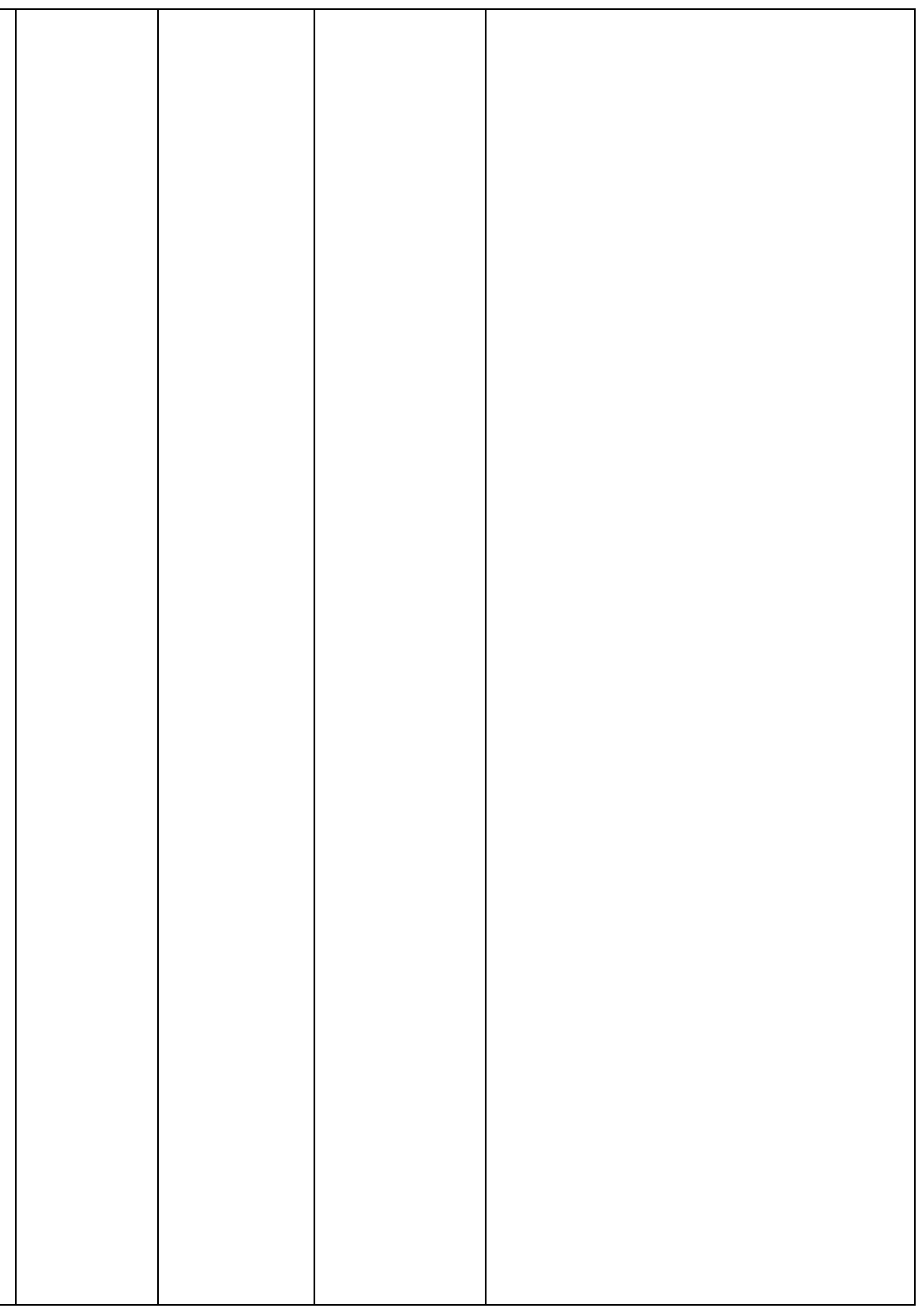




\begin{tabular}{|c|c|c|}
\hline $\begin{array}{l}\text { Pengaruh Pikiran: } \\
\text { - } \quad \text { Bahaya Seks Pranikah } \\
\text { - } \quad \text { Reaksi Orangtua } \\
\text { - } \quad \text { Pentingnya Sex Education } \\
\text { - } \quad \text { Efek Fisik dan Psikologis } \\
\text { - } \quad \text { Membuat Timeline Bertemu } \\
\text { - } \quad \text { Rasa Takut }\end{array}$ & $\begin{array}{c}\text { Informan } \\
1,2,3,4 \\
\text { dan } 5\end{array}$ & $\begin{array}{l}\text { Informan berpendapat bahwa setiap } \\
\text { pesan yang disampaikan dalam film } \\
\text { Dua Garis Biru memiliki pengaruh } \\
\text { terhadap pemikiran mereka masing- } \\
\text { masing. Setiap informan } \\
\text { mengemukakan pemikirannya } \\
\text { sendiri, dimana mereka beranggapan } \\
\text { bahwa film ini dapat memberikan } \\
\text { pengaruh terhadap pemikiran } \\
\text { penonton mengenai efek buruk dari } \\
\text { dampak seks pranikah. }\end{array}$ \\
\hline $\begin{array}{l}\text { Makna Pesan : } \\
\text { - Menghancurkan Masa Depan } \\
\text { - Kenikmatan Sesaat } \\
\text { - } \text { Rasa Penasaran } \\
\text { - Memiliki Risiko Tinggi } \\
\text { - Menghancurkan Psikis dan } \\
\text { Kepercayaan Diri }\end{array}$ & $\begin{array}{c}\text { Informan } \\
1,2,3,4 \\
\text { dan } 5\end{array}$ & $\begin{array}{l}\text { Informan beranggapan bahwa } \\
\text { makna-makna pesan yang mereka } \\
\text { terima mengenai dampak seks } \\
\text { pranikah sangat berpengaruh } \\
\text { terhadap masa depan pelaku. Kelima } \\
\text { informan memaknai pesan tersebut } \\
\text { dengan pendapat yang berbeda-beda } \\
\text { berdasarkan pemaknaan masing- } \\
\text { masing individu setelah menonton } \\
\text { film Dua Garis Biru secara penuh. }\end{array}$ \\
\hline
\end{tabular}

Sumber : Olahan Peneliti (2020)

Berdasarkan hasil analisis diatas, kelima informan berada pada posisi Dominant Reading, dimana kelima informan termasuk ke dalam producer of meaning yang berarti audiens aktif dalam menciptakan sebuah makna serta mampu menginterpretasikan pesan-pesan dalam media sekaligus membangun makna pesan sesuai dengan pengalaman sosial-budaya masingmasing audiens. Sesuai dengan teori yang dikemukakan oleh Stuart Hall mengenai analisis resepsi, mengacu pada teori encoding dan decoding yang memposisikan audiens ke dalam tiga posisi yakni dominant reading, negotiated reading, dan oppositional reading. Encoding merupakan sebuah proses dalam membuat pesan melalui kode-kode tertentu, sedangkan encoding dapat diartikan sebagai memahami kode-kode yang disampaikan melalui sebuah tayangan untuk memaknai sebuah pesan. Dalam hal ini kelima informan menjadi sebuah 
audiens aktif yang mampu memaknai pesan yang mereka terima sesuai dengan interpretasi masing-masing individu dimana pesan tersebut bisa saja tidak sesuai dengan makna pesan itu sendiri.

Dalam film Dua Garis Biru terdapat adegan yang menampilkan pesan-pesan terhadap dampak seks pranikah yaitu melalui adegan, pesan verbal, pengaruh terhadap pemikiran audiens, dan juga makna pesan yang terkandung didalamnya. Kelima informan memaknai pesan yang mereka terima mengenai dampak seks pranikah melalui adegan yang ada dalam film Dua Garis Biru termasuk ke dalam posisi negotiated reading, dimana kelima informan memiliki persepsi yang berbeda-beda tentang adegan yang mereka terima melalui film tersebut dalam artian beberapa informan memiliki satu pandangan terhadap satu adegan, sedangkan informan lainnya memiliki pandangan yang berbeda. Menurut kelima informan, adegan yang paling berpengaruh mengenai dampak seks pranikah dalam film tersebut mampu menampilkan emotional feel yang sangat tinggi melalui segala sisi.

Setelah adegan, selanjutnya ada unsur pesan verbal melalui dialog yang disampaikan mengenai dampak seks pranikah. Dalam hal ini, kelima informan memposisikan diri mereka pada dominant reading, dimana kelima informan menerima pesan yang disampaikan dalam film tersebut dan memahami makna pesan yang disampaikan alam artian informan memiliki pemahaman yang sama terhadap pesan yang disampaikan tanpa adanya penolakan. Menurut informan pesan verbal yang disampaikan dalam film tersebut sangat menunjukkan dampak dari seks pranikah melalui dialog para pemain, dengan tujuan untuk memudahkan audiens memahami makna pesan yang disampaikan oleh film tersebut.

Sama seperti unsur sebelumnya yakni pesan verbal, pada unsur pengaruh pemikiran audiens, kelima audiens juga menempatkan posisi mereka pada dominant reading. Dampak seks pranikah yang dapat mempengaruhi pemikiran kelima informan berbeda-beda melalui perspektif masing-masing individu setelah mereka menonton film Dua Garis Biru dan melihat pesan-pesan yang disampaikan dalam film tersebut. Menurut kelima informan, dampak seks pranikah dalam film tersebut sangat mempengaruhi pemikiran mereka terhadap seks pranikah dan menganggap bahwa seks pranikah tentunya berbahaya yang dapat menimbulkan efek buruk terhadap fisik dan juga psikologis terhadap pelakunya. 
Pada unsur yang terakhir yaitu mengenai pemaknaan seks pranikah dalam film Dua Garis Biru, kelima informan juga menempatkan posisi mereka pada dominant reading dimana informan memaknai pesan yang mereka terima setelah menonton film Dua Garis Biru secara penuh dengan pemahaman yang sama namun melalui sudut pandang yang berbeda-beda dari setiap informan. Mereka menerima makna pesan yang disampaikan dalam film tersebut mengenai dampak seks pranikah secara keseluruhan tentang risiko yang diterima oleh pelaku dan juga masa depan yang hancur akibat perilaku tersebut. Kelima informan juga tidak menyetujui perilaku seks pranikah yang dilakukan, karena menurut informan pada dasarnya hal tersebut dilakukan setelah menikah.

Dengan latar belakang informan yang berstatus hubungan sedang "berpacaran", diketahui dari kelima informan, dua informan pernah melakukan perilaku tersebut namun dengan kasus yang berbeda dan tidak sampai mengakibatkan kehamilan. Informan lainnya mengaku tidak pernah melakukan seks pranikah dengan pasangannya, dan semenjak menonton film Dua Garis Biru kelima informan mengaku untuk lebih berhati-hati setelah mengetahui dampak besar yang terjadi akibat perilaku seks pranikah. Kelima informan juga mengatakan bahwa film Dua Garis Biru mampu menyampaikan pesan kepada khalayak mengenai dampak seks pranikah untuk nantinya dijadikan pelajaran bagi anak-anak remaja sekarang agar tidak terjerumus kedalam pergaulan bebas serta pentingnya pendidikan seks kepada anak-anak zaman sekarang. Selain itu, informan juga berpendapat bahwa film ini juga menjelaskan pentingnya komunikasi yang terjadi antara orangtua dan juga anak agar terhindar dari hal-hal yang dapat menghancurkan masa depan seorang anak.

\section{SIMPULAN}

Hasil penelitian ini menunjukkan bahwa posisi kelima informan berada pada Dominant Reading mengenai pemaknaan mereka terhadap dampak seks pranikah yang ada dalam film Dua Garis Biru. Kelima informan memaknai dampak seks pranikah tersebut dan mengaku mendapatkan banyak pesan-pesan yang diterima mengenai bahaya dari perilaku seks pranikah. Mereka juga mengungkapkan bahwa setelah menonton film tersebut pemikiran mereka terpengaruhi dengan adanya seks pranikah yang banyak terjadi di era sekarang. Selain menerima pesan 
secara keseluruhan dari film tersebut, kelima informan juga menemukan pesan-pesan yang disampaikan secara verbal khususnya pada dialog-dialog tertentu yang disampaikan oleh para pemain. Adegan-adegan yang ditampilkan juga menampilkan emosional yang tinggi dari segala sisi khususnya dari orangtua ketika menghadapi permasalah besar seperti anak yang terjebak dalam seks pranikah. Menurut hasil wawancara dengan latar belakang informan yang sedang menjalani status "pacaran", perilaku seks pranikah akan membuat mereka untuk lebih bisa menjaga diri agar terhindar dari perilaku tersebut dan juga tidak akan mudah terpengaruh oleh status hubungan mereka yang sebenarnya dapat menjadi peluang untuk terjadinya hubungan seks pranikah seperti banyak yang terjadi pada zaman sekarang.

\section{DAFTAR PUSTAKA}

Baran, S. J., \& Davis, D. K. (2015). Mass Communication Theory: Foundations, Ferment, and Future. Cengage Learning. https://doi.org/10.4135/9781446262467

Barker, C. (2003). Cultural Studies Theory and Practice. Cultural Studies Theories and Practice.

Delabastita, D. (1989). Translation and mass-communication: Film and T.V. translation as evidence of cultural dynamics. BabelBabel Revue Internationale de La Traduction / International Journal of Translation, 35(4), 193-218.

https://doi.org/10.1075/babel.35.4.02del

Durham, Meenakshi Gigi and Kellner, D. M. (2006). Media and Cultural Studies, Keyworks. Representations. Blackwell Publishing. https://doi.org/10.1525/REP.2019.145.1.107

Kartika, B. A. (2015). Mengapa Selalu Harus Perempuan: Suatu Konstruksi Urban Pemenjaraan Seksual Hingga Hegemoni Maskulinitas dalam Film Soekarno. Journal of Urban Society's Arts, 2(1), 35-54. https://doi.org/10.24821/jousa.v2i1.1268

Khairunnisa, A. (2013). Hubungan Religiusitas dan Kontrol Diri dengan Perilaku Seksual Pranikah Remaja di Man 1 Samarinda. EJournal Psikologi, 1(2), 220-229. Retrieved from http://ejournal.psikologi.fisip-unmul.ac.id/site/wp-content/uploads/2013/10/ejournal pdf (10-03-13-10-14-57).pdf

McQuail, D. (2014). Mass Communication. Mass Communication. https://doi.org/10.4135/9781446262467

Nasrullah, R. (2018). Riset Khalayak Digital: Perspektif Khalayak Media Dan Realitas Virtual Di 
Media Sosial. Riset Khalayak Digital: Perspektif Khalayak Media Dan Realitas Virtual Di Media Sosial, 17(2), 271-287. https://doi.org/10.5614/sostek.itbj.2018.17.2.9

West, R., \& Turner, L. H. (2008). Introducing Communication Theory. Introducing Communication Theory Analysis Application. 